Western University

Scholarship@Western

Aboriginal Policy Research Consortium International (APRCi)

$12-2009$

\title{
Transnational Understandings of Australian Aboriginal Sporting Migration: Sporting Walkabout
}

John Maynard

Follow this and additional works at: https://ir.lib.uwo.ca/aprci

Part of the Sports Studies Commons

Citation of this paper:

Maynard, John, "Transnational Understandings of Australian Aboriginal Sporting Migration: Sporting Walkabout" (2009). Aboriginal Policy Research Consortium International (APRCi). 320.

https://ir.lib.uwo.ca/aprci/320 
This article was downloaded by: [University of Western Ontario]

On: 01 December 2012, At: 07:43

Publisher: Routledge

Informa Ltd Registered in England and Wales Registered Number: 1072954 Registered

office: Mortimer House, 37-41 Mortimer Street, London W1T 3J H, UK

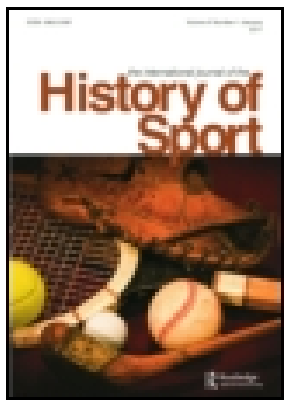

\section{The International J ournal of the History of Sport}

Publication details, including instructions for authors and subscription information:

http:// www. tandfonline.com/loi/ fhsp20

\section{Transnational Understandings of Australian Aboriginal Sporting Migration: Sporting Walkabout}

J ohn Maynard ${ }^{\text {a }}$

a Wollotuka School of Aboriginal Studies, Version of record first published: 17 Dec 2009.

To cite this article: J ohn Maynard (2009): Transnational Understandings of Australian Aboriginal Sporting Migration: Sporting Walkabout, The International J ournal of the History of Sport, 26:16, 2376-2396

To link to this article: http:// dx.doi.org/ 10.1080/09523360903457031

\section{PLEASE SCROLL DOWN FOR ARTICLE}

Full terms and conditions of use: http://www.tandfonline.com/page/terms-andconditions

This article may be used for research, teaching, and private study purposes. Any substantial or systematic reproduction, redistribution, reselling, loan, sub-licensing, systematic supply, or distribution in any form to anyone is expressly forbidden.

The publisher does not give any warranty express or implied or make any representation that the contents will be complete or accurate or up to date. The accuracy of any instructions, formulae, and drug doses should be independently verified with primary sources. The publisher shall not be liable for any loss, actions, claims, proceedings, demand, or costs or damages whatsoever or howsoever caused arising directly or indirectly in connection with or arising out of the use of this material. 


\title{
Transnational Understandings of Australian Aboriginal Sporting Migration: Sporting Walkabout
}

\author{
John Maynard
}

\begin{abstract}
This article will examine the impact of Aboriginal sporting participation and movement around the globe. The experiences, influences and inspiration that Aboriginal sporting men and women absorbed while travelling internationally have played a prominent role in changing the perceptions and understanding of Aboriginal people to the wider populace. The later stages of the nineteenth and early twentieth century were a period in which Aboriginal people were erroneously categorized as a dying race, belonging to the Stone Age and uneducable. However the influence of sport and travel ensured that Aboriginal cricketers, footballers, athletes, boxers and horsemen and -women played a part in challenging these erroneous perceptions. As a consequence sporting success played a vital role in inspiring other Aboriginal people to challenge the stigma and stereotypes that they were expected to endure and carry. The sporting arena was not just a venue for sporting participation but, I will argue, was responsible for generating and exposing Aboriginal people to a range of far-reaching influences, not least political ideology.
\end{abstract}

\section{Early International Contact and Movement}

At the time of British arrival on the Australian continent in 1788 Aboriginal Australians had already occupied the country for upwards of 60,000 years. One convenient invented myth which has been perpetuated since the arrival of the Europeans was that Aboriginal culture was static and unchanging. Aboriginal Australia was locked into some perpetual Stone Age of development, one in which they had survived simply through isolation in a protected cocoon away from the ravages/advancements of the rest of the world.

John Maynard, Wollotuka School of Aboriginal Studies. Correspondence to:

John.Maynard@newcastle.edu.au 
It is easy to overturn such long-held but nevertheless enduring fallacies. Aboriginal Australians had centuries of contact with an array of international visitors prior to the British arrival in 1788. These included the Portuguese, Dutch, French and Chinese, and these visitors influenced or impacted upon Aboriginal culture in a variety of ways. For example, the Macassans regularly visited northern Australia for upwards of several hundred years prior to 1788 to procure trepang, a delicacy much sort after in China. [1] The Macassan visitors were instrumental in establishing trade with the Aboriginal people of northern Australia, introducing new words and new items of technology such as dugout canoes, sail rigging, metal and glass. Aborigines served as crew on the boats and Macassans took Aboriginal women as partners.' [2] Aboriginal people gained work as crewmen on these boats and raises the probability that some Aboriginal people had ventured far from Australian shores many centuries ago, certainly as far as China. International connection therefore impacted on trade, employment and enhancing political/cultural knowledge.

After the British occupation in 1788, Aboriginal people were frequently taken back to Britain as exotic curios (which reflected an ongoing process of European conquest and domination - to publicly display the vanquished), first as curiosities and later as examples of the fine efforts of Christian civilizing. What started as a trickle in the late eighteenth century built to a steady flow throughout the nineteenth century.

In many instances it was not an Aboriginal choice; they were taken from their families, homeland and held as virtual prisoners. Roslyn Poignant's book Professional Savages highlights some of these sad stories, including a group of Northern Queensland Aborigines shipped to the United States to appear in dime museums, fairgrounds and circuses. They toured all over America and Europe, forced 'into the harsh world of commercial spectacle, the survival of the Aboriginal performers depended on the strengths they drew from their own culture and their individual adaptability. Few ever returned to Australia. Most died somewhere on tour.' [3]

There have been revelations of Aboriginal men serving in the Union Navy during the American Civil War and of Aboriginal people such as Anthony Martin Fernando taking their political discontent to the other side of the globe. [4] Fernando gained work as a boilerman on a ship to Europe in the later stages of the nineteenth century. He took to the streets in Italy, Switzerland and England, carrying placards and handing out pamphlets highlighting the ill-treatment of Aboriginal people in Australia. [5] In London he started a one-man campaign against Australia and regularly picketed Australia House. He covered himself with toy skeletons and pointed to them as he called out to passers by see 'what they are doing to my people in Australia'. [6] For decades Fernando waged an unrelenting protest and as late as 1938 he was still in the news. Once more in court, now aged 74, he remained unbowed: 'We are despised and rejected, but it is the black people who keep this country in all its greatness.' [7] Fernando died shortly after this court appearance and, as Goodall reverently describes, he had maintained 'his struggle against enormous odds, alone but unfailingly presenting his people's case on the other side of the world, in the heart of the land of the colonizers'. [8] 


\section{The Sporting Lifeline}

It was the unlikely and unexpected avenue of sport that offered Aboriginal people some hope of acceptance, understanding and survival. In the contemporary twenty-first century Aboriginal people are regarded as having extraordinary gifts as sportsmen and women across a wide range of sporting endeavours, particularly football, boxing and athletics. It certainly took Aboriginal Australians some time to gain not only acceptance on the sporting arena but even the right and opportunities to take part. Aboriginal Australia had developed a sporting culture long before European arrival on the Australian continent. Arguments have raged that in fact Aboriginal people were the original inventors of a form of Australian football. Writer Jim Poulter has recognized that 'the Gunditjmara tribe played a game called marn gook, or "game ball". A ball was made of possum skin and filled with pounded charcoal and bound with kangaroo sinews. Between 50 and 100 men a side played for possession for hours on end.' [9]

Early settler accounts of the 1840s testify that this game was predominately a kicking game. [10] The Aboriginal players apparently kicked 'the ball with the instep of the bare foot, and they made strong leaps - sometimes reaching 5 feet above the ground'. [11] Predominantly, though, traditional Aboriginal games were all about teaching skills, particularly agility and athleticism, which were integral in the hunting and gathering lifestyle. All games were taught and encouraged from a very young age to teach skills that were so important for survival.

\section{It Just Isn't Cricket}

The initial impact of European invasion upon Aboriginal life was catastrophic. The impact of disease, frontier violence, land theft and the rapid decline of resources has prompted some to estimate that the Aboriginal population of the continent had been reduced by somewhere between 60 to 90 per cent only a decade after the arrival of the British. The remnant of the Aboriginal population, particularly in the more heavily populated south-eastern states, was now in a battle of survival. Forced onto land that could provide little subsistence, some gained a lifeline through the sudden disappearance of the white workforce from the stock industry through the gold rushes. Pastoralists were quick to realize that Aboriginal workers knew the country better than anyone else, could track stock over vast distances, knew where water was, knew good grazing land and the changing seasons and did not have to be paid! These people became the backbone of the stock industry and became great horsemen and women. However, the greater unfortunate majority lived on the fringes of white towns and survived on a combination of traditional subsistence, scraps and benevolence from some humanitarians with compassion for Aboriginal suffering. In the later stages of the nineteenth century, state government-run Aborigines Protection Boards were established, in effect to smooth the dying pillow for a doomed race. The boards controlled every aspect of Aboriginal life, confining them on strict reserves under a board manager handing out blankets, tea, flour and 
sugar - an inadequate and unnutritious diet that would have a far-reaching negative impact on Aboriginal health and well-being even to the present day.

Certainly prior to the 1850s Aboriginal people had little connection with organized sport. However Christian humanitarians and those of a benevolent direction encouraged Aboriginal sporting participation as a paternalistic means of civilizing Aboriginal people. [12] In these early years horse racing and cricket were the most prominent arenas of sporting outlet. There were a number of prominent Aboriginal jockeys in Queensland, New South Wales, Western Australia and Victoria, the most notable the brilliant Peter St Albans, who as a 13-year-old rode Briseis to win Australia's greatest race, the Melbourne Cup, in 1876. [13] By the mid-nineteenth century it was noted that good numbers of Aboriginal people played cricket on missions, reserves and country stock stations: 'Rev. Mathew Hale, who established a missionary institution at Poonindie, near Port Lincoln in South Australia in 1850, believed that games and cricket in particular, could make Aborigines more industrious and moral.' [14]

The gentleman's game of cricket, embedded with its core value of fairness and equality, was to be sorely tested in providing an Aboriginal place at the mainstream crease. An early Aboriginal cricketer named Shiney or Shinal played cricket in Hobart, Tasmania in 1835. The tragedy of this man's story signifies the horror of Aboriginal experiences: 'On his death, Shiney was beheaded and the resident doctor sent the "specimen" to an Irish museum for preservation. Recent agitation by Tasmanian Aborigines resulted in his remains being returned and ceremoniously cremated in 1992.' [15]

Undoubtedly some Aborigines misguidedly believed that 'their prowess in sport, particularly in cricket and running, gave them a passport to the white man's world, even to his respect and friendship'. [16] Coranderrk, an Aboriginal reserve in Victoria became famous for the success of Aboriginal farming and producing, musicians, political activists and cricketers. A visit by the British naturalist H.N. Moseley in 1874 is responsible in recording the impact of cricket:

We found the cricket party in high spirits, shouting with laughter, rows of spectators being seated on logs and chaffing the players with all the old English sallies: 'Well hit!', 'Run it out!', 'Butter fingers!' etc. ... The men were all dressed as Europeans; they knew all about Mr W.G. Grace and the All-England Eleven. [17]

Coranderrk was not an isolated incident Aboriginal cricket teams were recorded as operating from Poonindie in South Australia, Deebing Creek in Queensland and New Norcia in Western Australia where a team known as the Invincibles played in Perth cricket for over a quarter of a century.

But it was the establishment of an Aboriginal cricket team in Victoria in the late 1860 s that is best remembered. This team initially played before a large crowd at the MCG in 1866 and the MCG and Sydney's Albert Ground in 1868. Hotel proprietor Charles Lawrence played a leading role in taking this team on a tour of England, the 
first Australian cricket team to do so. On the gruelling tour the team played 47 matches, winning 14 games, drawing on 19 occasions and losing 14. The team were unquestionably exploited and the gruelling programme was instrumental with the 'death of one player, Bripumyarramin ("King Cole") from pneumonia; the premature return home of Ballrinjarrimin ("Sundown") and Lytejerbillijun ("Jim Crow"), possibly because of illness; the arrest of Bonnibarngeet ("Tiger") for drunkenness and the general homesickness of most team members'. [18] Despite this, the tour was a great success and the team proved very popular: receipts of $\mathfrak{E} 5,416$ more than covered the costs of $\mathfrak{E} 3,224$, but sadly none of the players profited from this surplus: 'Many spectators undoubtedly watched the Aboriginal cricketers out of racial curiosity and to watch the associated sports carnivals when some players demonstrated their skills at weaponry, running backwards dodging cricket balls and throwing boomerangs.'

Two of the tourists deserve special mention: Johnny Mullagh and Johnny Cuzens were without question the stars of a very good team. Mullagh was afforded the tag of the 'black W.G.' [Grace] and his statistics were impressive: in England 'he played 43 matches, scoring 1,679 runs at an average of 22.51 and took 237 wickets at 9 runs each'. On the team's return to Australia Mullagh played with the Melbourne Cricket Club 'as a professional living with the lodgekeeper and caretaker at the Melbourne Cricket Ground'. [19] Sadly. on the point of his gaining inter-colonial selection, his position with the Melbourne Club was terminated, apparently through 'severe illness to his lungs'. [20] He returned to the Harrow country district of his birth and lived a life alone in the bush with a bunch of dogs he used for rabbiting. His cricketing skills, however, continued to be revered in these districts and he was constantly sought out if there was a match on. He amassed an impressive record and even was afforded the honour of captaining these white teams. Despite constant calls for his selection in Victorian sides, he was always overlooked. He was belatedly awarded his one and only representative match for Victoria when it played Lord Harris's visiting English team in 1879 . He made only 4 in the first innings but top-scored with 36 in the second: 'Mullagh's play was an exhibition in itself. His long reach, his cool artistic style, his judicious treatment of dubious balls, and his vigorous drives, called forth demonstrative applause.' [21] At the end of the match, Mullagh was presented with a bat and 'a purse of 50 sovereigns was collected for him on the ground'. [22] Mullagh could hardly be described as a political activist, but he carried a dignity that was beyond reproach "Told by an innkeeper while on tour that a room next to the stable was good enough for a "nigger", Mullagh a gentle man opted to sleep in the open yard while his white teammates slept soundly in the inn's comfortable beds'. [23] He played on until 1890 and died in 1891.

By the turn of the century Aboriginal opportunities to play cricket had declined. Placed under the strict tentacle control of the protection boards, they were largely segregated away from the wider community. There were a few notable exceptions who overcame rigid barriers to take part in the mainstream cricket arena: Albert Henry played seven times for Queensland from 1902 to 1905; Jack Marsh played for NSW on six occasions from 1900 to 1905; and the legendary fast bowler Eddie Gilbert played 23 
times for Queensland. Sadly all of these players and many others were despite outstanding talent denied the greater representative opportunities they richly deserved.

During the early 1920s a number of Aboriginal men and women in Australia were inspired by Marcus Garvey and Garveyism and set up a chapter of Garvey's Universal Negro Improvement Association in Sydney, Australia. [24] Intriguingly, there are a number of reports that Aboriginal people were in attendance with over 25,000 others at Garvey's first highly successful convention staged at Madison Square Garden in 1920. [25] Who these people were remains a mystery: they may well have been seamen as Garvey had established links and networks in the merchant marine and many black seamen operated as his agents. [26] Certainly the rise in 1924 of the Australian Aboriginal Progressive Association (AAPA), the first all-Aboriginal organized political group to form in Australia strongly evidences the influence of Garveyism. This political organization fought a bitter four-year campaign against the New South Wales state government's Aborigines Protection Board. They demanded land for each and every Aboriginal family in the country, protested against the board's actions of removing Aboriginal children from their families and fought to protect a distinct Aboriginal cultural identity. Sadly this organization was hounded out of existence by the police acting for the board in the late 1920s. Evidence uncovered reveals that the AAPA had strong links with sport and recognized its importance to Aboriginal communities. At a major conference in Kempsey, NSW, in 1925 and attended by over 700 Aboriginal people it was noted that among the delegates were many notable Aboriginal sporting identities who had made their impact in the arenas of cricket, football and aquatic sports. [27] Part of the conference programme on New Year's Day was devoted to a cricket match between the Burnt Bridge and Bowraville teams. [28] It was recorded that young Aboriginal men were joining the organization and had formed a cricket team and intended to help the fund of the AAPA by holding special matches. [29] A number of the high-ranking members of the organization were talented sporting icons; Johnny Donovan, who organized many of the northern braches of the AAPA, was described as a prominent and much respected community and sporting identity. It was stated that 'no cricket or football team is complete without his captaincy'. [30] Additionally Tom Lacey, treasurer of the central AAPA branch, was recognized as a prominent first-class cricketer and secretary Sid Ridgeway was a first grade cricketer with North Bankstown and renowned sailor. Ridgeway and two other members of the Karuah Aboriginal community had built their own sailing vessel and entered it in the Post Stephens regatta. [31] They were unbeatable, and after winning the sailing title three years in a row were awarded the trophy in perpetuity. [32]

\section{The Times are a Changing}

Boxing has been without doubt the sporting arena within which Aboriginal people have had their greatest success. It was one of the few avenues people had for escaping the power of the Protection Board. Undoubtedly it was financial return and exploitation that allowed this loophole. Boxing was very, very popular and big money 
could be made in unearthing a talented boxing protégé. Aboriginal boxing statistics remain impressive and run against the grain of under-representation in most sports. Despite the handicap of making up only 2 per cent of the population, Aborigines have produced 30 of the 225 boxing champions (15 per cent) in eight major Australian professional divisions over 50 years. [33]

Certainly the initial interest of Aboriginal people in boxing could be linked to an international influence. The visit to Australia in 1907 of African American boxing sensation Jack Johnson had far-reaching repercussions. Johnson was an articulate and politically charged individual, the Muhammad Ali of his day. Johnson displayed interest, knowledge and appreciation of traditional Aboriginal life during his visit. 'I spend most of my spare time in the art galleries and the museum,' he stated: [34]

My principle hobby is archaeology. When I visit your museum and see the numerous specimens of prehistoric man's art, your boomerangs of many varieties, your stone axes from various States and the many examples of Paleolithic and Neolithic man's skill - simply I envy you. America had its rude implements but they did not show anything like the same foresight. The Australian natives must have been geniuses to invent such weapons. [35]

Johnson had long been denied the opportunity of fighting for the world heavyweight crown, with the colour bar drawn against him by a succession of white champions. In Australia he had two fights, knocking out both opponents, Peter Felix and Bill Lang. Shortly before he returned to the United States he was given a farewell by a group in Sydney called the Coloured Progressive Association. This organization was comprised primarily of African American, West Indian and African transitional seamen, but recent research has revealed that future Aboriginal activists of the 1920s had links with this organization and were present at Johnson's farewell celebration. [36] Unquestionably coming into contact with such an outspoken figure as Johnson would have had an inspiring impact on these individuals. Johnson returned to Australia the following year when finally offered the opportunity of fighting for the world heavyweight crown against Canadian Tommy Burns. In one of the most talked-about sporting events of the twentieth century, Johnson annihilated Burns in the ring, with police eventually forced to jump into the ring and stop the one-sided punishment in the 14 th round.

The news of this great black victory spread around the globe and rapidly through the Aboriginal and Islander communities, where it was received with jubilation. A Solomon Islander who was present at the Burns-Johnson fight as a young boy later described it as 'the greatest day of my life'. [37] Years later Johnson himself recounted that during the break between rounds, his eyes surveyed the crowd, and he drew strength from a black man whom he saw in the audience:

As my gaze wandered out into the surrounding territory, I saw a colored man sitting on a fence watching the fight with open mouth and bulging eyes. My glance returned to him again and again. He was one of the very few colored people present, and he became a sort of landmark for me. [38] 
Fears of the consequences of such identification of black Australians with Johnson's victory underlay attempts to suppress the news of Johnson's win in such places as the Solomon Islands, "where it was felt the "natives" might take an inappropriate message from it'. [39] A writer in the Bulletin screamed: 'Johnson's behavior in the ring was objectionable, so much so that if it had happened in America, someone would have shot him dead to the cheers of the crowd and given the film as defense evidence and got a verdict of "justifiable homicide". [40] Randolph Bedford, writing for the Melbourne Herald, did not hold back in his scorn of Johnson. 'Already the insolent black's victory causes skin troubles in Woolloomooloo,' he moaned. 'An hour after, I heard a lascar laying down the law of Queensberry to two whites, and they listened humbly. It is a bad day for Australia.' [41]

Johnson was afraid of no one, black or white, and insisted on being treated with respect. This was completely beyond the understanding of the majority of white people, who expected and demanded that blacks knew their place. On Monday 18 March, the day after Johnson's farewell, Johnson broke the nose of his white manager, A.A. McLean, and was charged with assault at the Water Police Court in Sydney. The Sydney Sportsman reported that 'McLean called Johnson a big black b-, whereupon the nigger knocked him down'; Johnson was fined $\mathfrak{E} 5$ and $\mathfrak{E} 11$ s costs in default of a two-month prison sentence, which he paid and then departed. [42] It was this sort of behaviour that signalled to black people across the globe, including Australia, that they did not have to be subservient to anyone.

The significance and impact that Jack Johnson made on the international black population around the globe cannot be underestimated. Johnson returned to the United States, where he knocked out Stanley Ketchel and then the 'Great White Hope', Jim Jeffries. After the Johnson-Jeffries fight, race riots erupted in the United States. Whites reacted angrily when Jack Johnson first seemed to toy with Jeffries and then knocked him out in the 15th round. The violence of the race riots made worldwide headlines. [43] The whole assumption and unquestioned aura of white supremacy had been firmly knocked out by Jack Johnson:

The fists of Jack Johnson had rattled the white world - even from the farthest outposts of the British Empire came angry reports about bumptious natives. White America now trembled for its women. White manhood had shrivelled. While a black mistress - especially in the south - was considered a passable fashion accessory for a white man it was unthinkable that white women might begin submitting to the charms of black men. Johnson had long flaunted his affairs with white women at a time when a black man could be lynched for even the slightest sexual suggestion to one. In fact, during Johnson's reign as champion 354 black men were lynched -89 for alleged offences against white women. [44]

The joy Aboriginal people had taken in Johnson's victory over Burns in Sydney had not abated and evidence reveals that they had continued to follow his exploits around the globe: 'His victories and his outspoken assertiveness won him frenzied racial 
vilification from Australia's press and the enthusiastic support of many Aborigines'. Both the black and white population looked forward to the match against the muchvaunted Jeffries: 'Johnson's notoriety while in Australia and the high degree of racial hostility associated with his fights here and in the USA meant that many people were eagerly following the fight in 1910.' [45]

A squatter on the north coast of NSW, Cunningham Henderson, later recorded his memories of the Johnson-Jeffries fight. Henderson's recollections offer a valuable insight of the differing black and white sentiments surrounding this major sporting event. Henderson recalled that he was helping his friend, Tom Yabsley, to muster cattle:

It was the day of the Johnson-Jeffries fight in America. Because of Johnson's colour the black boys took a keen interest in the fight and were discussing it. Just then a blasting shot went off in a stone quarry a few miles away, which we heard plainly. Yabsley turned quickly to Alfie and said - 'Did you hear that?' 'Yes Boss What that feller?' 'That was Jeffries hitting Johnson!' Alfie quickly cupped his hand, held it to his ear, and striking a listening attitude, said - 'No Boss, I never heard the people shout!' (meaning there was no applause) The laugh was against the boss.

The fact that Henderson remembered this incident, that he recalled the Aboriginal men discussing the fight and the superficially light-hearted banter between the whites and blacks about it, all suggest that its significance ran deeply for them all. [46]

Jack Johnson went on to hold the world title for another five years, but eventually fled the United States because of trumped-up charges of trafficking white women. In 1915 Johnson lost the title in Havana to Jess Willard, although controversy over the decision and aftermath of the fight rages to this day. Johnson claimed that he was made an offer that if he lost the fight the charges against him would be dropped and he could return to the US. He did return but was jailed for nine months, and though he returned to boxing was never given the chance to regain the lost title. Eventually he would be regarded along with Joe Louis, Sugar Ray Robinson and Muhammad Ali as one of the greatest fighters of all time and an inspiration to future generations of black athletes. The dominance that white society had held and obviously believed was seriously shaken through the triumphs of Jack Johnson.

Jerry Jerome was one individual who undoubtedly drew confidence from the ring exploits of Jack Johnson. He became the first Aboriginal Australian boxing champion, winning the middleweight crown in 1912. Three outstanding world-class boxing champions came in the decades ahead: Ron Richards, Dave Sands and Lionel Rose. Richards and Sands won Commonwealth titles, while Rose defeated Fighting Harada in Tokyo 1968 to be crowned bantamweight champion of the world. All three gained widespread adulation for their ring exploits and all married white women, a very uncommon event for their time periods. None of these boxers challenged wider white society and appear to take their sporting success as acceptance by white society. After losing his titles, money and wife, Ron Richards 
lived on the streets and died a lonely, beaten social wreck. Dave Sands, in contrast, was tragically killed in a truck accident in his prime, before he had the opportunity of fighting for a world title or before white acceptance had disappeared. Rose followed a similar path to Richards and battled problems with alcohol and depression after his career ended. In his prime he was unquestionably the most popular man in Australia, an idol of unprecedented adulation. A bigger crowd awaited his return at Melbourne airport from Tokyo after winning the world title than greeted the Beatles on their visit. An examination of Rose and his comments at the time reveal the levels of control and power that was exerted over Aboriginal people. In total contrast to Jack Johnson, success apparently compromised one's background and a whitewashing of skin colour. Both tennis champion Evonne Goolagong and Rose were highlighted as having escaped the apathy of alcohol and wandering laziness which for generations was the accepted and encouraged view of Aboriginal people. Acceptance by mainstream Australia was conditional and governed by fairly stringent rules and regulations. Primarily you had to keep winning. Many books and articles of Aboriginal heroes openly reinforced the stereotypes of the period. As an example, Lionel Rose in his book Lionel Rose: Australian gives clear evidence of the thinking of the day. His book was put together with the aid of a white journalist, Rod Humphries, and reinforced many of the popular and totally untrue stereotypes of the time. Rose states, or is made to state, that in defence to accusations from Aboriginal people that he had moved away from his people, 'in fact he was not a full-blood but only close to three quarter caste'. [47] Further Rose highlighted that the:

authorities have learned that handouts breed further laziness. I would be the same if somebody provided a house and gave me money every now and then to keep going. I know I wouldn't be too inclined to go looking for work. But the authorities now are working on a system of giving the Aboriginal an opportunity to help himself. The time will eventually come when all Aborigines are assimilated. [48]

Rose misguidedly pulls no punches (excuse the pun), stating that:

Assimilation will come through the children with proper guidance through education. The older generation are to set in their ways to make drastic changes to their way of life. The sophistication of the city has proved too much too soon for many of them, and they sink into drinking, which is the start of their downfall. [49]

Rose also expressed the opinion that 'an Aboriginal has very strong community ties, tribal if you like to call it that. It is an unwritten law from way, way back that whatever one Aboriginal owns has to be shared with everybody else. I have broken from that now and whatever I earn is my own'. [50] Rose was also critical that another 'difficult problem for the Aboriginal to overcome when he moves into advanced society is the urge to go walkabout. I've broken that habit too'. [51] If Rose 
was to reflect on the utterings attributed to him some four decades ago it would likely draw forth a cringe of discomfort, especially seeing as his book was written while he was champion of the world and toast of the country. The backslapping brigade soon stepped from his side once his title and money had gone; quite simply he was then portrayed as another failed Aborigine gone wrong.

In comparison, another Aboriginal sporting icon of the period, jockey Darby McCarthy, was sophisticated articulate and politically attuned. The strict regimented control exerted over Aboriginal people and their segregation away from the rest of the community had had a far-reaching detrimental effect, not least with denied sporting opportunities. It was not until the vibrant 1960s that an Aboriginal sporting political voice began to be heard. The emergence of Darby McCarthy coincided with this time of dramatic social change. The 1960s witnessed an enormously divisive war in Vietnam, a highly visible civil rights movement in the United States. It was the time of music, protest and oppressed groups around the globe breaking the constraints of colonial domination. There was a spark and growing confidence in Aboriginal people to speak out and challenge the authorities over their unjust treatment. Journalist Bill Weate, writing in 1966, described that when McCarthy had 'commenced his career as a jockey he was determined to overcome the defeatist attitude which is adopted by many of his race. By making a supreme effort he was anxious to prove the apparent colour bar was no hindrance to his career.' [52] Compare where Weate is coming from to another report from around the same time period; this time the voice is wholly and solely McCarthy's. A newspaper reader had complained of a reporter's continual reference to Darby being Aboriginal; McCarthy replied:

I think the man is sincere and trying to be fair but he misses the whole point. If any newspaperman wants to do me a favour he can call me an Aboriginal as often as he mentions my name - because that is what I am and if I am going to be a success it is important that I be known as an Aboriginal success. [53]

McCarthy was a man for the changing times, not just a jockey of outstanding talent: he blazed his own path. One of a family of 12 children born in the western Queensland town of Cunnamulla, McCarthy had a harsh start to life - 'at Cunnamulla, we lived in a tin humpy between the town cemetery and sewerage outlet. Blacks weren't allowed up in the town mind you.' [54] He would go onto ride the winners of some of Australia's greatest races and ride internationally in Germany, France, England and Ireland for people such as the Rothschilds, Wildensteins and Prince Aly Khan. In France he lived in a two-storey French mansion complete with maid and chauffeur. McCarthy's career nosedived in the late 1970s, falling foul of racing officialdom; weight problems, alcohol and depression all played a part in the slide from the top. But McCarthy remains to this day a proud Aboriginal man not afraid to speak out against any injustice facing his people. He remains critical of the Australian reconciliation process - 'what are we reconciling' he has asked. 'It's 
supposed to have been a war? There's been no war. There's just been murder and a mass genocide of this country and our people.' [55]

\section{The Global Impact of the World Game}

It is quite clear that an Aboriginal political voice from a sporting perspective was not present prior to the 1960s. Sporting success meant that Aboriginal people were more inclined to be written about as Australian successes, in many cases ignoring their cultural background. Charles Perkins, arguably the most charismatic and recognized Aboriginal leader of the twentieth century, was quite blunt during this period: 'This is what happens today with Aboriginal sportsmen and women. They are apologized out of existence. Sporting fame gains them acceptance, not as Aborigines or even as people, but merely as sports stars - everyone's heroes.' [56]

Perkins is of course worth greater examination, as he was an outstanding soccer player. Perkins was in fact one of three great Aboriginal soccer players of the period that included John Moriarty and Gordon Briscoe. These men followed near identical and connected paths to the top. Perkins was adamant that 'Aboriginal Affairs and soccer have been my passions and where I could work out my problems through both of those two things. ... Soccer was where I got my satisfaction, my fulfilment.' [57] Charles Perkins was born at the Aboriginal reserve near Alice Springs in the Northern Territory. His parents were Arrente and Kalkadoon people. He was taken from his mother at the age of ten and placed in St Francis Anglican Home at Semaphore, SA, founded two years earlier by father Percy Smith for Aboriginal boys. It was here among many other Aboriginal boys who had been taken from their families, including his cousin Gordonn Briscoe, Johnny Moriarty, Vince Copley and Wally McCarthur, that he attended school and learned to play soccer.

Later, after leaving the home and working in a variety of jobs, Perkins enrolled as a student with the University of Sydney and was only the second Aboriginal person to graduate from an Australian university. In 1965, he led a group of students emulating the US civil rights movement's 'Freedom Rides'. The Australian 'Freedom Rides' will remain forever one of the pivotal moments in Aboriginal history, and they provided the perfect political and public launching-pad for Charles Perkins. The students, in visiting outback towns in New South Wales, used the media to draw attention to the deeply segregated inequality of Aboriginal existence. Aboriginal people were denied access to hotels, swimming pools and in some cases even the streets of these towns.

From that point and for the remainder of his life, Perkins was at the forefront of Aboriginal political activism. He played a role through the Foundation of Aboriginal Affairs in the campaign that led to the overwhelming 'yes' vote in the 1967 referendum resulting in the federal government taking power over Aboriginal affairs from the states. Throughout his dynamic and often turbulent political career, Perkins was compared to such individuals as Martin Luther King Jr and Nelson Mandela. He 
died in 2000, leaving a void in Aboriginal political affairs that that has been impossible to fill.

But it is the intersection and pivotal point of connection with other boys such as Moriarty and Briscoe at the St Francis Home and their introduction to soccer that will be examined here. It was their acceptance not just onto the soccer field but into the wider cosmopolitan soccer community and international travel that played some part in moulding all three into inspiring Aboriginal political leaders in the decades ahead.

All of the boys were to feel the full brunt of racism and prejudice that was an everyday part of the Australian landscape during their young lives. Denied access to so much, Perkins reflections clearly identify the pain he felt as a young man:

It really hurts you; it slices right to your heart. You can't handle it. I thought to
myself, what have I done? How can I rectify this? Can I scrub myself white? Can I
do something to myself? Nothing. They really make you feel ashamed of yourself
and you feel less of a person as a consequence. It undermines your confidence
above all else, and your dignity and your self-respect. Then it develops a reaction
within yourself of hatred. It pierced me right to the core of my heart. I've never
forgotten those things and I never will. You carry them to your grave. They're scars
on your mind. [58]

As a consequence acceptance was something that made a great and lasting impact on Charles Perkins. Soccer was responsible for opening doors and delivering a glimpse of a level playing field. Perkins was adamant that 'It brought me into the migrant community where I found great satisfaction, no prejudice, no history of bad relations, no embarrassing comments or derogatory remarks, they welcomed me into the fold and I've been there ever since.' [59]

The large influx of European migrants into Australia after the end of the Second World War had a marked impact and explosion of interest in soccer. Clubs formed with a diverse variety of ethnic backgrounds including Polish, Italian, Greek, Hungarian, Croatian and Scottish, to name but a few. Gordon Briscoe reflected on the impact of these arrivals:

When these 'New Australians' came onto the scene, they didn't question our
background, because they were people who'd had difficulties, they'd suffered from
war damage, they'd suffered from [not] having the freedom to move wherever they
wanted to, they were probably being employed for the first time, struggling, but yet
still wanting to practice their culture, which was soccer.... So when they saw us,
they didn't question our background and our racial heritage ... and they respected
us, because we could do the things that entertained them. [60]

The launch of Perkins, Moriarty and Briscoe's soccer careers could all be tied to a now legendary minor soccer game played while they were at the St Francis Home. A state under-18 representative team was practising on a football pitch close to the home. All the Aboriginal boys were sitting on a fence watching the team practise 
when an official came over and asked if the boys would like to form a team and play a practice match against the state team. The Aboriginal boys jumped at the chance. The officials had no idea that these boys were mad on sport and were excellent at any football code. John Moriarty recalled that at the home

We'd play during the holidays from eight o'clock in the morning, from after breakfast, right through till dark. Sometimes we'd even play in the moonlight; we were so full of energy. All we had to play soccer with was a tennis ball, but we'd play six, seven, eight, ten a side often in quite confined spaces in the courtyard at the home. That was good fun, learning to control the ball and so on. [61]

On the field the Aboriginal boys annihilated this representative team 12-0. It wasn't a game but a shame. There were a number of officials present from the Adelaide Port Thistle Soccer Club and they immediately signed up a number of these budding stars. Perkins was a first grade soccer player at the age of 15; by the age of 20 one he had moved to Budapest, the most powerful club in South Australia at the time. During this time period Budapest won a host of trophies and Perkins was awarded the South Australian Player of the Year award. John Moriarty, Gordon Briscoe and Vince Copley also initially joined Port Thistle. Moriarty also made the first team before the age of 18 . A number of the Aboriginal kids including Briscoe and Copley made the state intermediate team. Moriarty played for a number of clubs including International United, Birkalla and then back to Port Adelaide. Both Perkins and Moriarty made such an impact that they became regulars in the South Australian senior representative team.

On one inter-state trip in 1960, Moriarty became aware as an Aboriginal that the soccer authorities had to gain permission from the Protector of Aborigines for him to travel with the team:

This is an insult, having to seek permission from someone I've never met. Who is this person who has control over my life? Being an independent minded person, and having just turned twenty-two, I thought I was representing the State in soccer in my own right, which was as an Australian. I thought, 'this is an indignity that no-one should suffer'. [62]

Charles Perkins, meanwhile, received an invitation from the English first division club Everton to go to England for a trial in 1959. Perkins was encouraged by friends to take the chance - it could only broaden his knowledge of 'world situations' and benefit him on his return to Australia. [63] Perkins was faced with enormous disadvantages travelling. He set sail on an Italian liner in the cheapest class, with little money or clothes. The trip to Europe was a nightmare, he suffered severe seasickness and ate little. He disembarked in Genoa and took a train to Paris where his bag was stolen. He arrived in London unshaven, with only the clothes on his back and must have resembled a tramp to the Everton officials there to meet him. He was given only two weeks to get himself into shape for his trial and received no encouragement from either the players 
or officials. Understandably the trial did not go well; disheartened and lonely for home he often walked the Liverpool streets at night. He gained employment at the Mersey shipyards as a fitter, but racism forced him to look elsewhere. He gained a job as a coalminer in Wigan and lived with a former friend from the St Francis home, Wally McArthur, who was now a world-class rugby league player. The mining community had no problem accepting Perkins as one of their own. He was given a football opportunity with Bishop Auckland, then regarded as the best amateur team in Britain. He was an outstanding success and, now fully fit and acclimatized, his performances warranted the notice of some first division clubs including one offer of a trial by the legendary Matt Busby and Manchester United. Perkins, now suffering acute homesickness, turned down the offer and accepted a return ticket to Australia paid for by the Croatia club back in Adelaide. Despite the negativity of his initial disappointments in Britain, he could at the conclusion of his stay reflect:

I've had a good time here. I've seen a lot of things, met a lot of people and found a lot of happiness. The English people in Wigan and Bishop Auckland or England generally, I suppose, are wonderful. They are decent people and give you a fair go. They treated me better than I was ever treated in Australia ... I was on my way back to my country, my people and problems. [64]

He encouraged his cousin Gordon Briscoe to join him with the Adelaide Croatia club. Initially Briscoe had played with Beograd and Polonia after leaving Port Adelaide, but had moved to the country through work and had continued to play soccer in Murray Bridge and Port Lincoln, where he had represented that district in both soccer and Australian Football. Perkins and Briscoe had a great season with Croatia, winning the Ampol Cup, and Perkins was back in the South Australian representative side.

Meanwhile John Moriarty achieved a wonderful milestone at the conclusion of the 1960 state championships in Melbourne, where his performances were of such a level that he gained selection in the Australian side to tour south-east Asia. He was the first Aboriginal selected to play soccer for his country; sadly he would be denied the opportunity. Australia was expelled by the world governing body FIFA for poaching players from European clubs without paying for them. The ban lasted nearly two years and sadly Moriarty would not be given the opportunity again:

None of this changed the fact that I'd been picked to represent my country. I was on top of the world. I really felt I'd earned my place and I was walking on air. Of course, not getting to play was upsetting, but I was also still seething about needing permission to play soccer interstate. In fact, that was one of the things that brought me to the Aboriginal rights issues. And it did so at the beginning of a time of great activity. [65]

In 1961 Moriarty joined the Italian-supported Adelaide Juventus team. The perks were obvious: eating at fine Italian restaurants and wearing tailor-made Italian suits. 
Moriarty proved a great favourite with the Juventus fans. He had previously been approached about possible opportunities with English clubs Tottenham Hotspur, Arsenal and Everton, but a lack of financial resources had curtailed his ambitions. It was during this time period that Moriarty, along with Perkins, came into contact with a number of influential non-Indigenous Aboriginal rights campaigners such as Dr Charles Duguid and Don Dunstan, who encouraged their involvement in Aboriginal affairs. Moriarty outlined: 'I started taking petitions around. Dunstan spurred us on, and we gained a lot of support, in the form of signatures and petitions, that were presented in the State Parliament.' [66]

Gordon Briscoe decided to follow the example of Charlie Perkins and travelled to England to further his football career. He started playing for an amateur team Hendon Rovers just outside London but was spotted and signed by first division club Preston North End. Preston was a club with a proud past and also an Australian connection - Joe Marston spent five seasons with the club in the early 1950s playing in a losing FA Cup Final in 1954. Briscoe during his stay more than held his own, playing with the $B$ and $C$ teams, reserves and made a couple of firstteam appearances. Famous England international Tom Finney was assistant coach at the time. Briscoe supported the comments of Perkins that in England he found great acceptance:

Well, they didn't know what an Aboriginal person was, and because of our background, we'd say, 'I'm an Aboriginal' ... and they'd say, 'Well what's that?', and then we'd have to explain our background. But, they treated you in the same European way, they were very self-interested. And that's how we were able to get past some of the problems. If you could play soccer, amongst people who knew something about soccer, you were put on a pedestal ... if the coach said, 'You do this and you do that', and you did that, and then you did that well, you were given an opportunity to go further up the slippery pole. [67]

After returning to Australia Briscoe's soccer career scaled down, and in 1971 he accepted a position as a field officer with the recently established Aboriginal Legal Service in Sydney. In the same year he and Shirley Smith established the Aboriginal Medical Service in Redfern and persuaded Fred Hollows to become its first medical director. Hollows as director and Briscoe as assistant director later cooperated in running the national trachoma and eye health programme, which had screened 110,000 people by 1981, when they resigned from it in protest against Commonwealth government proposals to pass Aboriginal health funding to the states. In 1972 Briscoe attempted to enter federal parliament. As an Australia party candidate, he unsuccessfully contested the NT seat in the House of Representatives against the sitting Country Party member Sam Calder. Briscoe moved to Canberra in 1974, where he worked for the Commonwealth department of Health, Aboriginal Hostels Ltd, Central Australian Aboriginal Congress and AIATSIS. Briscoe went to university, gaining a bachelor of arts, master of arts and PhD from the Australian National University. Recently retired as an academic historian, his special interests 
are relations between Aboriginal workers and pastoral station management, the Maralinga atomic testing programme and health policy.

In 1963 John Moriarty finally decided to join the European caravan and set sail for Europe with a group of friends. He made an error in timing it had been his intention to break into European soccer but arrived in October 'it was mid season and it was impossible to break into it'. He went on a European sojourn with his friends, visiting over 30 countries, but still carries disappointment over not pushing harder with his soccer opportunities:

One of my big regrets of that time is that I didn't settle with a soccer club. I just trained in Sweden. The truth is, I was really enjoying myself. I was twenty six and what really stuck out for me was meeting and mixing with people. I had always been told I was very narrow in outlook; that trip overseas broadened my outlook considerably. ... Even so I regretted not playing soccer in England, or not giving it a go there. I lived with that for the rest of my life. I'll never know if I'd have made it. [68]

Moriarty was also forthright on the difference of attitude between the people in England and Australia at that time: 'They enjoyed life; they enjoyed people for what they were. If you were a likeable person, they didn't discriminate on colour - at least the people I met didn't. In Australia discrimination was enshrined in law.' [69] After nine months of wonderful memories and travel, Moriarty was called back to Australia to play for Adelaide Juventus in the Australian soccer championships, the club paying for his flight back to Australia. He arrived back in Adelaide on 11 June 1964 'and went straight from the airport to a Juventus home game, at Hanson Reserve. When I walked onto the ground the crowd forgot the game for a moment and turned to greet me. I'll never forget that welcome. People still mention that moment to me.' [70] In 1965 his soccer career was prematurely brought to an end in a savage collision with a goalkeeper. The force of the impact ripped one cartilage completely off; the one on the other side was half off. Surgery attempted to put his knee back together. After months of rehabilitation he made a comeback lasting only two games before his knee once more gave out, ending what had been a great career.

One stellar career ended and another began. Moriarty was a foundation member of the local Aborigines Progressive Association and the SA branch of Federal Council for the Advancement of Aborigines and Torres Strait Islanders (FCAATSI). In 1967, he completed a bachelor of arts degree in history and geography at Flinders University and in 1971 was awarded a Churchill Fellowship. He moved to Canberra in 1973 to take a position with the Department of Aboriginal Affairs and rose rapidly. In 1974 he served with several advisory groups and subsequently moved to Melbourne and Adelaide as a regional head. The following year he was appointed national chairperson of National Aborigines and Islanders Day Observance Committee (NAIDOC). Moriarty left the DAA in 1988 to work as a private consultant in Aboriginal affairs to public and business agencies. He and his wife Ros also run design firms Jumbana (Moriarty's Aboriginal name) and Balarinji, producing high-quality fashion goods 
inspired by Aboriginal arts and crafts, most famously with the designs worn by Qantas staff and carried by a number of their elaborately designed planes.

In 1963 Charles Perkins decided that Sydney was the place for him now, and a university degree was on his high priority list: 'When I came to Sydney my deep interest in sport was transferred more to Aboriginal affairs. I realized that Sydney was the centre of the mass media and this was where I could get an opinion across to people in Australia.' [71] Perkins had in his mind that soccer could pay his way through university; he trained with the Bankstown soccer club for a week but was told he would not make the team. A fortunate meeting with an old soccer chum put him in touch with the wealthy Greek-backed club Pan Hellenic. He had a training run with the club and the following Sunday in a match against arch rivals Prague he was given a run in the second half. Perkins was never one to let an opportunity go begging. He had an outstanding debut, scoring a second-half hattrick that sent the Greek fans mad with delight. He was an instant celebrity with the Greek community.

Within three months Perkins was captain of the club and in six months was captain-coach. Perkins' goals and objectives were now fixed in sight: 'With my new status and the financial rewards it brought. I was now in a position to pursue my immediate objective of a university career, and beyond that, I hoped a revolution in race relations in Australia.' Perkins graduated from university. Soccer, after so many years, now took a back seat as Charles Perkins embarked with a group of students on the Freedom Ride and to Aboriginal political immortality.

In conclusion,sporting participation has played a prominent role in the lives of many Aboriginal people across so many decades. It sometimes opened doors and in many instances shut them just as quickly. Sporting success and travelling opportunities broadened the outlook of many, whose experiences not only changed their own lives but impacted onto many others. Yet clearly prior to the 1960s an Aboriginal sporting political voice was largely non-existent. For Aboriginal people sporting success came at a high cost, in many instances costing them their very identity. But from the 1960s people such as Darby McCarthy, Charles Perkins, John Moriarty and Gordon Briscoe used sport to challenge the injustice and inequalities of Aboriginal life. These men never lost sight of who they were and the important role they played not just in the sporting arena but the world stage, pressing for important social change for the betterment of their people.

\section{Notes}

[1] Kiem and Smithson, Colonial and Contact History, 190; Mulvaney, Encounters in Place, 22.

[2] Kiem and Smithson, Colonial and Contact History, 191.

[3] Poignant, Professional Savages, front cover.

[4] T. Foenander, 'Australasian Natives in the Union Navy', 8 Feb. 2000, available online at http:// home.ozconnect.net/tfoen/anz.html accessed 8/28/2005, accessed 8/28/2005, accessed 28 Aug. 2005; Maynard, 'Transcultural/Transnational Interaction and Influences on Aboriginal Australia', 204. 
[5] Goodall, 'Aboriginal Calls for Justice', 5.

[6] Ibid.

[7] Ibid.

[8] Ibid.

[9] Booth and Tatz, One Eyed, 10; The Age, 8 June 1993.

[10] Goldblatt, The Ball is Round, 8.

[11] Blainey, A Game of Our Own.

[12] Cashman, Paradise of Sport, 132.

[13] Maynard, 'Vision, Voice and Influence', 28.

[14] Cashman, Paradise of Sport, 132.

[15] Booth and Tatz, One Eyed, 40.

[16] Ibid., 41.

[17] Ibid.

[18] Willis, 'Cricket Team', 239.

[19] Whimpress, 'Johnny Mullagh', 98.

[20] Ibid.

[21] Ibid., 99.

[22] Ibid.

[23] The Australian, 8 Jan. 2008, 12.

[24] Maynard, Fight for Liberty and Freedom, 32.

[25] Martin, Race First, 42.

[26] Martin, Marcus Garvey, 99.

[27] Macleay Chronicle, 7 Oct. 1925.

[28] A.N.A., 7 Jan. 1926.

[29] Macleay Chronicle, 7 Oct. 1925.

[30] Daylight, 30 Oct. 1926.

[31] Grafton Daily Examiner, 29 Dec. 1926.

[32] Conversation with Kevin Ridgeway, Woolgoolga, 1998.

[33] Cashman, Paradise of Sport, 131.

[34] Wells, Boxing Day, 78.

[35] Ibid.

[36] Maynard, Fight for Liberty and Freedom, 25.

[37] Corris, Lords of the Ring, 94.

[38] Wells, Boxing Day, 245.

[39] Ibid.

[40] Ibid.

[41] Wells, Boxing Day, 197.

[42] Sydney Sportsman, 20 March 1907.

[43] See, for example, 'Race Riots in America, 19 deaths, many hurt and 5,000 arrested' (headline), Daily Express (London), 6 July 1910.

[44] Wells, Boxing Day, 228, 229.

[45] Goodall, Evans Head History Report.

[46] Ibid.

[47] Rose, Lionel Rose, 148.

[48] Ibid.

[49] Ibid.

[50] Ibid

[51] Ibid.

[52] Weate, Racetrack, 45.

[53] Tatz, Obstacle Race, 249. 
[54] Maynard, Aboriginal Stars of the Turf, 110.

[55] Ibid., 115

[56] Perkins, Aboriginal Stars of the Turf, 54.

[57] Australian Biography VII, Charles Perkins (camera roll 2), May 1998.

[58] Read, Charles Perkins, 48.

[59] Australian Biography VII Charles Perkins, 5 May 1998.

[60] Interview with Gordon Briscoe, Canberra, 7 Oct. 2004.

[61] Moriarty, Saltwater Fella, 105.

[62] Ibid.

[63] Perkins, A Bastard Like Me, 41.

[64] Ibid., 51.

[65] Moriarty, Saltwater Fella, 118.

[66] Ibid., 119-20.

[67] Interview with Gordon Briscoe.

[68] Moriarty, Saltwater Fella, 136, 137, 138.

[69] Ibid., 137.

[70] Ibid., 138.

[71] Perkins, A Bastard Like Me, 66.

\section{References}

Blainey, G. A Game of Our Own: The Origins of Australian Football. Melbourne: Information Australia, 2003.

Booth, D. and C. Tatz. One Eyed - A View of Australian Sport. Sydney: Allen \& Unwin, 2000.

Cashman, R. Paradise of Sport - The Rise of Organised Sport in Australia. Melbourne: Oxford University Press, 2002.

Corris, P. Lords of the Ring: A History of Prize Fighting in Australia. Sydney: Cassell Australia Ltd, 1980.

Goldblatt, D. The Ball is Round - A Global History of Football. London: Viking Press, 2006.

Goodall, H. 'Aboriginal Calls for Justice'. Aboriginal Law Bulletin 2, no. 3 (1988).

Goodall, H. Evans Head History Report for the application for a native title determination. No. NG 6034 (2003):70-1.

Kiem, P and M. Smithson. Colonial and Contact History. Melbourne: Longman, 2001.

Martin, T. Race First. Boston, MA: Majority Press, 1976.

Martin, T. Marcus Garvey: Hero. Boston, MA: Majority Press, 1983.

Maynard, J. Aboriginal Stars of the Turf - Jockeys of Australian Racing History. Canberra: Aboriginal Studies Press, 2003.

Maynard, J. 'Vision, Voice and Influence: The Rise of the Australian Aboriginal Progressive Association'. Australian Historical Studies 34 (2003).

Maynard, J. 'Transcultural/Transnational Interaction and Influences on Aboriginal Australia'. In Transnational History: Breaking Down Border Protection, edited by M. Lake and A. Curthoys. Canberra: Australian National University Press.

Maynard, J. 'In the Interests of Our People: The Influence of Garveyism on the Rise of Australian Aboriginal Political Activism'. Aboriginal History 29 (2006).

Maynard, J. Fight for Liberty and Freedom - the Origins of Australian Aboriginal Activism. Canberra: Aboriginal Studies Press, 2007.

Moriarty, J. Saltwater Fella. Melbourne: Viking Books, 2000.

Mulvaney, D.J. Encounters in Place: Outsiders and Aboriginal Australians 1606-1905. Brisbane: University of Queensland Press, 1989. 


\section{J. Maynard}

Perkins, C. A Bastard Like Me. Sydney: Ure Smith, 1975.

Poignant, R. Professional Savages: Captive Lives and Western Spectacle. Sydney: University of New South Wales Press, 2004.

Read, P. Charles Perkins. Sydney: Allen \& Unwin, 2001.

Rose, L. Lionel Rose: Australian. Sydney: Angus \& Robertson, 1969.

Tatz, C. Obstacle Race: Aborigines in Sport. Sydney: University of New South Wales Press, 1995.

Weate, W. Racetrack. Sydney: Thorn Publications, 1996.

Wells, G. Boxing Day: The Fight that Changed the World. Sydney: HarperCollins, 1998.

Whimpress, B. 'Johnny Mullagh: Western District Hero or the Black Grace?' Aboriginal History 18 (1994).

Willis, I.H. 'Cricket Team'. In The Encyclopedia of Aboriginal Australia. Canberra: Aboriginal Studies Press, 2004. 